Emilija Nikolić

UDK 711.52:902(497.11)

Archaeological Institute, Belgrade

Original research article

emilij@gmail.com

Received: April 08, 2010

Jelena Anđelković

Accepted: August 02, 2010

Archaeological Institute, Belgrade

jelenandjelkovic@gmail.com

Dragana Rogić

Archaeological Institute, Belgrade

\title{
ARCHAEOLOGICAL PARK AS A PRODUCT OF EMOTIONAL DESIGN: DESIGN AND ORGANIZATION OF A PARK BASED ON THE EXPLORATION OF VISITORS' EMOTIONS
}

\begin{abstract}
Methods of presentation within an archaeological park are always related to the period of history which is represented, butalso to the atmosphere in which the park is created. However, any form of representation must be subordinated to observer and his experience. There is no universal organization of archaeological parks, but in different scientific fields of sociology, psychology and philosophy, principles can be found upon which individual presentations are functioning and evoke similar reactions by every observer. By applying a model originating from the experience of these sciences, architects, planners, designers and management of archaeological parks can together reach adequate proposals for creation of physical elements and processes which make the park itself. A special role in this approach belongs to the scientific field that has long been known in architecture and design, apropos in theories of perception and acceptance of space and that is phenomenology. The creation of elements, processes and finally of the complete area of archaeological parks, thus obtains all characteristics of emotional design.
\end{abstract}

Key WORDS: ARCHAEOlOGICAL PARK, EMOTIONAL DESIGN, PHENOMENOLOGY, PRESENTATION, TOURISM, VIMINACIUM.

\section{INTRODUCTION}

Professor of history of architecture and urbanism at Cornell University, Medina Lazansky (D. Medina Lasansky) (2004), describes tourism as one of the world's largest industries. After archeological excavations in the eighteenth century, historical places are slowly becoming "have been redesigned and packaged for mass consumption via various venues of mass media, scholarship and popular myth" (Lasansky 2004: 1) Architects and designers, planners and urbanists, artists and scientists, politicians and entrepreneurs, but also local population and tourists all together convert historical sites into tourist destinations. Organization and design of all tourist

* The article results from the project: Viminacium, Roman city and military legion camp - research of material and non material of inhabitants by using the modern technologies of remote detection, geophysics, GIS, digitalisation and $3 D$ visualisation (no 47018), funded by Ministry of Education and Science of the Republic of Serbia. 
sites around the world, including archaeological parks, arise from different experts thinking about perception and interpretation of the place by residents or tourists, their behavior caused by a variety of presentations, but also with the experience that they bring. In 1999 economists Joseph Pine II and James H. Gilmore predicted that the economy of experience will replace agrarian, industrial and service economy. (Pernecky and Jamal 2010) However, it is important to emphasize that tourist operators with their services cannot provide experience of visitors, but only create atmosphere or the environment itself in which they can experience it. (Murray, Foley and Lynch 2010) Tourist spots thus become "a culturally created spectacle" which can be felt and understood by different people in different ways. (Lasansky 2004: 2)

In the last decade, emotional design has become a very important direction in the scope of design research field. The study of human emotional responses to the environment allows teams of designers to discover different ways of human acceptance of some product, including options for its design. Design relates to people, that is why perceptions and feelings of designers and consumers play a major role in the success of the product. (Formosa 2007) The topic of this paper is presentation of the model of the archaeological park whose application has the aim to enhance positive experiences of its users, apropos visitors. The model is based upon the theory of emotional design and two researches of different authors in the field of sociology and psychology. After a theoretical explanation of work, based on this model, a study on a selected example of the archaeological park can be deduced, which explores sources of visitors' emotions, reveals their interpretations, and finds opportunities for design of creation of "tangible elements" and "intangible processes"1 (Pui Ying LO 2007: 5 of 18)

1 The author Cathy Pui Ying Lo in her research describes tangible elements as tangible objects, their functions, layout and presentation, while the mechanisms of offering tangible elements and different services she described as
Archaeological park thus represents a tourist product of experience economy, whose creator is emotional design.

\section{EMOTIONAL DESIGN AND THEORY OF DONALD NORMAN}

Emotional design is an approach to design that emphasizes the importance of positive emotional responses caused by the users. (Pui Ying LO 2007) With this approach, the field of design research and design practice, have been extended outside the function, form and usability of products on the emotional dimension, enriching user's experience. (Pui Ying LO 2007)

According to Donald Norman, a professor of psychology, philosophy and computer science at several universities across the United States, there are three different aspects of design that we can perceive in a product. (Norman 2004) Visceral aspect is related to the appearance of the product, its sound, its smell, and every other feeling which it awakes at the first moment of encountering with it. Behavioral aspect includes the easiness or difficulty with which we use some product and our satisfaction or dissatisfaction as a result of that. Reflective aspect carries with it a rationalization and intellectualization of a product, apropos creates the final impression in the minds of consumers. Responses of users' to visceral aspect of design of some product are automatic evaluation of its perceptual features and their rapid classification. (Norman 2004) Such reactions are not based on experience or extensive knowledge about the meaning of objects, and sense at this level of design is unconscious and not to be interpreted. (Norman and Otorny, 2006) This is the aspect which any product can easily be based upon, because the reactions to it are equal for all people and all cultures. (Norman 2004) In behavioral aspect of design, it's all about func-

intangible elements. 
tion and use of a product. Donald Norman writes about it as follows: “Appearance doesn't really matter. Rationale doesn't matter. Performance does." (Norman 2004: 69) Before creation of design, it is necessary to understand the needs and ponder the behavior of those who will use a product. (Norman 2004) Responses to this design are not biologically based, but have been taught, so here skills and routines are important, which vary from person to person and from culture to culture. (Norman and Otorny 2006) Processes at this level are still unconscious and automatic, but since skills and routines we attain with learning and thus in this processes we include experiences and expectations, yet awareness is present. (Norman and Otorny 2006) The reflective aspect of design has to do with message and meaning which a product carries. Reflection is the highest level of intellectual functioning in a person where we find review, understanding of one's actions, guilt, but also emotions such as pride, shame, admiration and gratitude. Processes at this level are conscious. (Norman and Otorny 2006) Operations at reflective level determine the overall impression of a product for users, so at this level negativities of some of the previous aspects are diminished. (Norman 2004) The impression reaches its end, through "reflection - in retrospective memory and reassessment". (Norman 2004: 88). This aspect of design is thus the only way related to the experience which we permanently carry after use of a product and that "a personal touch and a warm interaction... a pleasant reflective memory" that "can overcome any prior negative experiences". (Norman 2004: 88) This aspect of design was influenced by experience and culture, age and social groups, but also fashion, however, it can be different for individuals in different times and depending on situation in which it is located. (Norman and Otorny 2006).

As design has three aspects, thus our cognitive and emotional systems have three similar levels of receiving affections from the outside which are constantly coliding with each other. (Norman 2004) What people really do can be quite different from what they think they do. Our behavior is mainly subconscious and then it is made of visceral and behavioral reactions. Many of our opinions are already determined before they reach consciousness, and reflective reaction, apropos consciousness, in the processes of information in brain comes later. (Norman 2004) The appearance and usage value of objects play a relatively insignificant role in the acceptance of a product by consumers. The most important thing is the connection with the object, associations which a person has about it and memories which are awaked with it. We are not related to the object itself, but to the meaning it carries and the feeling which is produced in us. (Norman 2004)

No successful product can be based only on one aspect of design. Different products generate different reactions by different observers. That is why designer must know his own target group of users and design with which we provide experience to a user must originate from consideration of all of the three aspects. (Norman 2004)

\section{MODEL OF AN ARCHAEOLOGICAL PARK BASED UPON THEORY}

An archaeological park consists of archaeological objects, modern service facilities, communications that connect them, but also different processes, apropos cultural and entertainment shows that are taking place in it. Although methods of presentation in an archaeological park are linked to history that is represented, they are also linked to people and area in which the park is located today, so every form of representation must be orientated towards the viewer and his experience. We can say that there is no universal organization of an archaeological park, but general principles can be established upon which individual performances are functioning and thus causing a 
relatively similar response of every observer.

In this paper, a model of an archaeological park that creates connections between tourists' emotions and tourist offers of the park is proposed, with an emphasis on design. Therefore, an archaeological park we observe represents a product based upon three aspects of emotional design by Donald Norman. However, to get the model, it is necessary to develop spatial and organizational principles from these aspects, from which recommendations for the creation of concrete physical elements in the park could originate.

Researchers Karen Puren, Ernst Drewes and Vera Roos (2006) set up three spatial principles for design and organization on the example of a proposal for the improvement of one archaeological site in South Africa. These principles, only modified, can be applied to every archaeological park. An important segment of their research is that all three spatial principles derived from considering concept of place's spirit. According to Christian Norberg-Schulz, the spirit of place ( $g e-$ nius loci) is an ancient Roman concept, according to which every being has his own genius, apropos his own spirit who guides him. (Norberg-Schulz 1980) The Spirit of place thus gives life to people and places, follows them from birth to death and determines their nature or essence. (NorbergSchulz, 1980).

The first principle which the authors appoint can be connected to visceral aspect of design, apropos visceral level of receiving affections. They call it the feeling of coming to another place - sense of arrival. According to them, this feeling is related to clear identification that we are within an area, increasing its visual legibility and contributes to a feeling of welcome which it provides. This is achieved by setting visible elements at the input places which are pre-defined with traffic solution. Their design must emphasize the passage from the outer to the inner environment. This is important that visitors get a sense that they are within an archaeological park, apropos within one place which evokes different feelings from the place which is beyond it. This design must be in accordance consistent with the character of external, natural environment, lest to disturb our sense of space which is inside. (Puren, Drewes and Roos 2006)

The second principle can be related to behavioral aspect of design, apropos behavioral level of receiving affections. Authors call it sense of orientation. Tourists must be able to orientate themselves within the site. The quality of overall legibility of a particular place is reflected in its structure, which implies places of movement (roads, pedestrian paths, etc.) and public spaces (squares, social contents, etc.). There are proposed plates on nodes of communication and names of roads, and everything with the aim of better visitors' orientation. Names of roads should reflect identity of a site, as seen by today's local residents, which may serve to reinforce their identity as a community. Gravel roads and pedestrian paths essentially reflect the character of the area and visitors use them more than arranged roads, so they are recommended. By its surface, the main road should be separated from the secondary ones. It is necessary to use different materials at the starting points of roads, change of direction or at their ends. The edges of roads should be accentuated to emphasize the road itself, which can be achieved with planting of local trees or using diverse roadsides. Contents of social life have a role of node when some place is in creation. Main node may be the place of economic, educational, cultural and informational contents. The character of nodes should be in accordance with places in which they are located. Most of parks are located outside the city, so the character of their nodes should not be urban or suburban, but rural. (Puren, Drewes and Roos 2006).

The third principle we associate with reflective aspect of design, apropos reflective level of receiving affections. According to the authors mentioned above, this is sense of experience. 
(Puren, Drewes and Roos 2006) According to Christian Norberg-Schulz, modern tourism is proving that experience of different places is the main human interest. (1980) According to the authors Puren, Drewes and Roos (2006), it is necessary to emphasize those natural qualities which create feeling of the place for visitors to their extent, apropos those points where the spirit of the place is the strongest. Places in archaeological park should be linked, physically or through the concept of architecture, to create a strong public structure throughout the site. In this way, a network of small public spaces arises to increase the overall experience. What is meant with the implementation of this principle is the harmonization of designers' interventions with previously brought plans of height regulation and zoning. With this a defined line of horizon is protected, which is very important for the perception and experience of space, as a pre-designed development of the area. (Puren, Drewes and Roos 2006)

Since the visceral aspect of emotional design is completely dependent on the first, immediate influence of a product to the user and his reactions, the product simply "has to feel good, look good". (Norman 2004: 69) Archaeological park has to attract visitors immediately, with the appearance of the first plate at the entrance and the smell of grass beside the road. As for behavioral aspect, everything in the archaeological park has to function flawlessly. The spatial organization of the park must be conducted thus that all roads pass through important historical contents of the park, and their intersections have cultural, service or entertainment contents. After fulfilling both the first and the second aspect of design and besides man's natural desire for knowledge about the past and the human fascination with ruins, the third, reflective aspect of design must be successful. It provides an unforgettable experience for tourists.

Archaeologist and professor of archeology at universities in England, Tim Copeland (2004) researches and sets out three forms of presentation at an archaeological site, which we can observe as recommendations for the creation of various elements of the organization further designing influence on visitors. This author has developed a theory according to researches of American psychologists in the field of theory of learning, Jerome Seymour Bruner.

\begin{tabular}{|c|c|c|}
\hline ENACTIVE REPRESENTATIONS & ICONIC REPRESENTATIONS & SYMBOLIC REPRESENTATIONS \\
\hline experimental archaeology & photographs & plans \\
\hline touching & drawings & excavation reports \\
\hline re-enactments & reconstructions & gudio tours \\
\hline walking around the site & 3D views & guidebooks \\
\hline & models & lectures \\
\hline & TV programmes & \\
\hline & information panels & \\
\hline & maps & \\
\hline & multimedia presentations & \\
\hline & the layout of the site & \\
\hline & directional signs & \\
\hline
\end{tabular}

Chart 1. 
The first form of presentation Tim Copeland called enactive (through action) and it is linked to various events in which visitors of the park are physically engaged. Another form is iconic and it is linked to presentations from the domain of visual media. The third form author called symbolic and associated it with different written and sound presentations with words and numbers. (Copeland 2004) As a part of the result of research Copeland has assigned specific elements of organization and processes to each of the three forms of presentation mentioned, (Copeland 2004) which we observe as products (Chart 1.). In order to make each of these elements and processes act as a successful product, it must be based upon all of the three aspects of design, apropos act on all three levels of receiving affections of users. However, for each product one aspect always predominates and the product has its greatest impact on user at one of three levels. It depends on the purpose of the product, but also on user's character. Accordingly, the three kinds of presentations apropos their elements and processes can be linked to certain prevailing levels of receiving affections. Action form of presentation can be connected to the reflective level, iconic form with behavioral and symbolic form with the visceral level of receiving affections.

Some of the many researchers of presentations in archaeological parks have concluded that tourists prefer exhibitions of crafts, skills, costumes and weapons, but also partial reconstruction of buildings and representations of past events with actors. (Copeland 2004) Some other researchers have concluded that the most successful in keeping tourists' attention are also performances with costumed actors and animals, as well as films and historically furnished rooms. (Copeland 2004) Different studies have shown that presentational panels and book guides do not help tourists much in understanding what is displayed. (Copeland 2004) Comparing these studies with a previously established relationship of aspects of design and types of presentations, actually their elements and processes (Chart 1.), the theory of Donald Norman (Norman 2004) is confirmed, according to which the reflective aspect of the design plays a major role in understanding the meaning of a product or process by users. Behavioral aspect of design is somewhat less important for this understanding, while emphasizing the visceral aspect designers achieve the lowest success for long-term acceptance of a product.

The conclusion based on the research of Tim Copeland is that with design of exactly those elements and processes which the author assigned to his groups of presentations, it affects visitors and their emotions in a way which is pre-determined. Thus, designers and architects can focus their activities on those elements which are important for a certain level of receiving affections, depending on situation in which a certain element is located.

From these theories and researches the model of

\begin{tabular}{|c|c|c|c|}
\hline ASPECTS OF DESIGN & SPATIAL PRINCIPLES & $\begin{array}{c}\text { REPRESENTATIONAL } \\
\text { MEDIA }\end{array}$ & $\begin{array}{c}\text { EMOTIONAL RESPONSES } \\
\text { OF THE VISITORS }\end{array}$ \\
\hline visceral & sense of arrival & symbolic & $\begin{array}{c}\text { sense of being } \\
\text { welcomed when we } \\
\text { first enter the site }\end{array}$ \\
\hline bihevioral & sense of orientation & iconic & $\begin{array}{c}\text { pleasure when we use } \\
\text { the park offer }\end{array}$ \\
\hline reflective & sense of experience & $\begin{array}{c}\text { unforgettable } \\
\text { experience after we } \\
\text { leave the park }\end{array}$ \\
\hline \multicolumn{3}{|c|}{ making visitors' emotions and experiences positive } \\
\hline
\end{tabular}

Chart 2 
archaeological park originates (Chart 2), which aims to develop positive emotions and experiences of visitors. With further, practical research among visitors of a certain park, we can obtain details about design and organization of the park, apropos the arrangement, look, color, size, sound or smell of the elements and processes that make a park. Model of an archeological park connects theory and research across three levels of receiving affections from the environment, assignment of a certain spatial principles and types of presentations to the relevant aspects of design. Developed emotions of visitors can be acceptance at the first contact with the park, which takes place on the visceral level, satisfaction in individual situations as a feature of the process at the behavioral level, and then a memorable experience as a result of receiving affections from the environment at the reflective level.

\section{RESEARCH BASED ON A MODEL}

In order to concretize theoretical recommendations for design and spatial organization of archaeological park, and according to the previously obtained model, practical research on a selected example can be carried out. Urbanists, architects and designers create space, but it becomes a place only at the end of a process, in which its inhabitants and visitors participate, apropos those who use it and experience it. (Pui Ying LO 2007) As Donald Norman writes, quoting other authors "the best that the designer can do is to put the tools into their hands". (Norman 2004: 224) Therefore, practical research relates to different methods of observation and inquiry of visitors and interpretation of their reactions and responses.

This practical research can be accomplished at any archaeological park, and the first step in developing some research is setting of basic questions on which it should give an answer. In the case of this research, these are the following questions:

1 What are specific physical elements and processes of design and spatial organization of a selected park which influence visitors' emotions and experience?

2 Which emotions and what kind of experience is caused with each of the elements and processes?

3 What are the characteristics of design and spatial organization of a chosen park which can reduce negative emotions and experiences and to increase the positive ones? It is therefore necessary to choose an appropriate approach to research. For this paper, we can choose an interpretative phenomenological approach. According to David Seamon, professor of architecture at Kansas State University and researcher in the field of human behavior in accordance with the environment (environment-behavior research), every object, event, situation or experience that one can see, hear, smell, physically or intuitively feel, know, understand or survive, can be a topic of a phenomenological research. (Seamon 2000) According to the author, phenomenology is, in simple terms, interpretive study of human experience. (Seamon 2000) Tomas Pernecky and Tazim Jamal, professors of tourist sciences at the universities of New Zealand and Texas, write that phenomenology in tourist sciences serves as a theoretical method for describing or understanding tourists' experiences, but also the local community, service providers and any other interest groups who takes part in the phenomenon of tourism. (2010) The aim of interpretative phenomenological approach thus becomes research of the way in which participants understand and experience life around them as well as their own lives. (Smith and Osborn 2008)

Data for this study can be collected with various qualitative methods. Among these methods there are inquiries, in the form of questionnaires or in different forms of interviews, personal diaries of examinee, observation of examinee 
by service research, discussions within the focal groups, various visual methods such as collecting photos or videos by examinees, based on preset requests of examiners, and other. Questions to which examinees give answers must be composed by experts from different scientific fields. In the research framework among visitors of an archaeological park, questions should be related to impressions made with concrete physical elements in the park itself and to processes which are taking place in it. It is important to note and understand the similarities and differences in perception, understanding and experiences of the environment, and that among all inquired visitors. The analysis of obtained data is then practiced based upon interpretative phenomenological approach. Data obtained from each tested participant are analyzed separately, and the ultimate results of all analyses represent answers to pre-asked questions of research related to design and spatial organization of the park.

In respect of design, conclusions should show what elements and processes from three types of presentation of adopted model, in certain park develop positive or negative emotions of each of the examinees. It is important to find out whether the reason for negative emotions is design itself, and if so, how it can be improved. It may happen that some of the mentioned presentation elements in a park studied do not exist and it is necessary to introduce them as a novelty. It is possible to conclude that some of the elements are no longer required as part of certain park's offers, perhaps because in such environment they do not affect the emotions of the majority of examinees, apropos do not influence them at any level of receiving affections. Conclusion related to the organization of an archaeological park shows which elements of the spatial organization of the park, implied with the three spatial principles in the model, are not in accordance with these principles, apropos do not provide a sense of place, a sense of orienta- tion, to most of the visitors, or possibly develop a negative experience. It is possible to conclude that some contents no longer have a place within the park, because most visitors do not use them any more. From this the decision follows about the need of their further existence or about the improvement of overall organization by changing the existing or introducing new contents.

Data interpretations obtained from all users give a conclusion on which improvement of the design of some elements and processes is based, as well as the spatial organization of a park, because maybe they do not performed their prevailing aspect of emotional design that is implied, but also new elements and contents are introduced, which in time have proven their justification. In the framework of visceral and behavioral aspects, the data obtained help to create proposals for design of concrete objects which will affect our senses apropos organization and design which will enable a better functioning and interrelationship of the park area, while in connection with the reflective aspect, different social events or individual performances are anticipated.

For future practical research with the help of the model obtained, authors of this paper propose the archaeological park Viminacium. ${ }^{2}$ This park was chosen because of a small ammount of visible material remains which cause numerous visitors' reactions. This is achieved by ancillary facilities, but primarily with different stories and presentations which introduce visitors into the park, guide through its expanse and finally conduct out of it.

2 Viminacium was the capital of the Roman province of Upper Moesia, and its administrative, military, commercial and production center. However, today this Roman city, which is located near the mouth of the river Mlava into the Danube, twelve kilometers far from Pozarevac in Serbia, mostly is under the ground. Although the research of the site began back in the end of 19th century, the development of archaeological park has just begun in 2002, and excavated sites have become available for tourists in 2006. Since then, the development of the archaeological park is rapidly taking place. In 2009 Viminacium was visited by 72,000 tourists. (information taken from: Maksin, M. et al 2011: 340) 


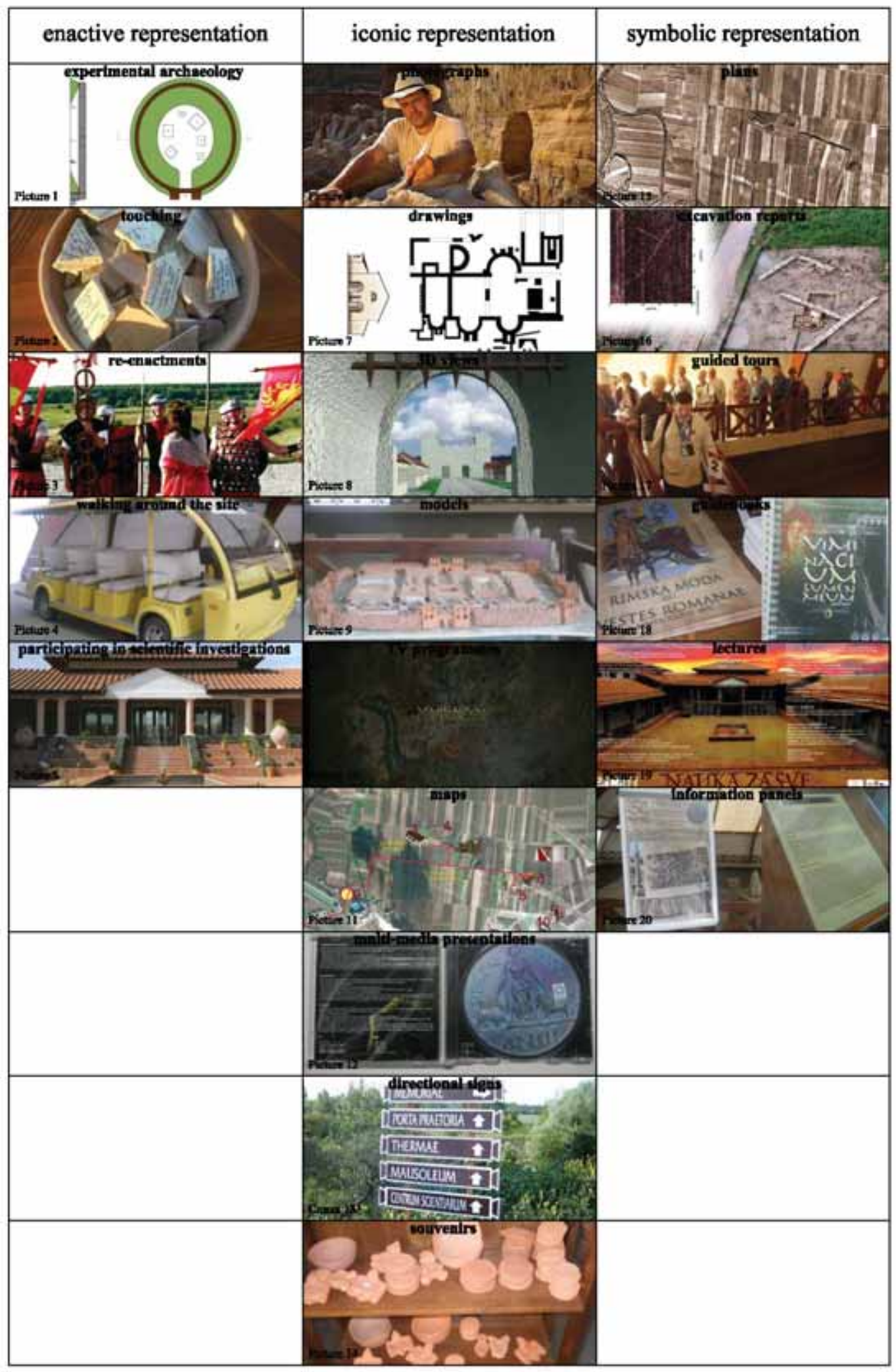


Long ago, the archaeological park Viminacium thus became a product whose creator is emotional design. However, this park was created and continues to develop with spontaneous processes which consist of thinking about visitors' perception, interpretation and behavior caused by a variety of presentations, then check and test of these presentations, and ultimately expectation of their efficiency. By applying the model proposed, through conducted practical research, in the future it could be quicker to reach creation of new, always successful elements and processes of this archaeological park, which would thus expand its tourist offer. Also, practical research would immediately point out to the existing successful elements or processes which will cease to be successful in the future, so with the results' analyses of such research different suggestions for their improvement would be obtained.

\section{CONCLUSION}

In this paper, we have tried to create a model of an archaeological park with representation of a theory from the domain of design and two studies from the fields of sociology and psychology. The basis of this model originates from the theory of emotional design by Donald Norman, while the concretization in design itself follows a model obtained from various researches. The conclusion of this paper is the confirmation of a thesis from its beginning, which asserts that all aspects of design are necessary in order to make an archaeological park function as a successful product. According to three aspects of design, the best presented archaeological park is the park in which all of the three spatial principles are accomplished and all three groups of presentations are represented. Individual elements and processes in the frame of presentation of the park have to be changed or replaced in time, depending on a particular park.

The paper shows that reflective aspect of emotional design makes the greatest impression on consumers of a product, creates the deepest emotions, and provides final experience. It is necessary for them to wish to use that particular product again. This means that with the prevailing action at the reflective aspect of design within an archaeological park, a visitor's desire to return to the same place is created. The first evidence of the validity of Viminacium as a product of emotional design, even without the performed proposed practical research, we can see if we analyze chart 1 and the above mentioned forms of presentation in the park (see appendix). It is interesting to see the richness and diversity of presentations within all of the three types. The most common are iconic presentations, apropos small, easily accessible and easily achievable physical elements which are usually most numerous, both in theory (chart 1) and in practice (there are usually in all of the archaeological parks). It is important to check the efficiency of all types of mentioned presentations with further practical research, and most of attention should be paid to the development of action presentations which make the greatest impression on visitors. In a number of archaeological parks, action presentations almost do not exist. However, in the archaeological park Viminacium, a large number of presentations of this type create an unforgettable feeling of experience for visitors. It is therefore necessary to recognize all presentations which have a negative influence, as well as those which positively influence visitors, in accordance with these to arouse procedures of their promotion, but also to establish some new elements and processes of presentation which have not yet existed. 


\section{BIBLIOGRAPHY}

\section{Copeland, T. 2004}

Presenting Archaeology to the Public: Constructing Insights On-site, in: Public Archaeology, N. Merriman (ed), London: Routledge, 132-144.

\section{Formosa, D. 2007}

Design, Emotions, and How People Think, presented at: Emerging Trends in Design Research (IASDR -International Association of Societies of Design Research Conference, 12-15 November 2007), accessed 05 March, 2011, http:// www.sd.polyu.edu.hk/iasdr/proceeding/papers/ Design,\%20Emotion,\%20and\%20How\%20People\%20Think.pdf

\section{Lasansky, D. M. 2004}

Introduction, in: Architecture and Tourism: Perception, Performance and Place, D...M.Lasansky and B. McLaren (eds), New York: Berg, 11-12.

\section{Maksin, M. et al. 2011}

Održivi razvoj turizma u Evropskoj uniji i Srbiji, Beograd: Institut za arhitekturu i urbanizam Srbije.

\section{Murray, N., Foley, A. and Lynch, P. 2010}

Fáilte Go Sláinte: Understanding the Tourist Experience Concept, presented at: Current Challenges and Future Opportunities (Tourism and Hospitality Research in Ireland Conference, 15-16 June 2010), accessed 27 March 2011, http://www.shannoncollege.com/wp-content/uploads/2009/12/THRIC-2010-Full-Paper-N.-Murray-et-al2.pdf

\section{Norberg-Schulz, C. 1980}

Genius Loci - Towards A Phenomenology of Architecture, New York: Rizzoli.

Norman, D.A. 2004

Emotional Design: Why We Love (or Hate) Every- day Things, New York: Basic Books, A Member of the Perseus Books Group.

\section{Norman, D.A. and Ortony, A. 2006}

Designers and users: Two perspectives on emotion and design, in: Theories and Practice in Interaction Design, S.Bagnara and G.CramptonSmith (eds), Mahwah, NJ: Lawrence Erlbaum Associates, 91-103.

\section{Pernecky, T. and Jamal, T. 2010}

(Hermeneutic) Phenomenology in Toursim Studies, Annals of Tourism Research, vol. 37, no.4: 1055-1075, accessed 27 March 2011, http://www.scribd.com/doc/48023303/Hermeneutic-Phenomenology-in-tourism-studies

\section{Pui Ying LO, K. 2007}

Emotional Design for Hotel Stay Experiences: Research on Guest Emotions and Design Opportunities, presented at: Emerging Trends in Design Research (IASDR -International Association of Societies of Design Research Conference, 1215 November 2007), accessed 05 March, 2011, http://www.sd.polyu.edu.hk/iasdr/proceeding/papers/Emotional\%20design \%20for\%20hotel $\% 20$ stay $\% 20$ experiences_\%20Research $\% 20$ on $\% 20$ guest $\% 20$ emotions $\% 20$ and $\% 20$ design $\% 20$ opportunities.pdf

\section{Puren, K., Drewes, E. and Roos, V. 2006}

An Exploration of Sense of Place as Informative for Spatial Planning Guidelines: A Case Study of the Vredefort Dome World Heritage Site, South Africa, International Journal of Human and Social Sciences, vol.1, no.3: 190-197, accessed 07 March 2011, http://www.waset.org/journals/waset/v28/v28-40.pdf

\section{Seamon, D. 2000}

A Way of Seeing People and Place: Phenomenology in Environment-Behavior Research, in: Theoretical Perspectives in Environment-Behavior Re- 
search, S.Wapner, J.Demick, C.T.Yamamoto and H.Minami (eds), New York: Plenum, 157-178.

Smith, J.A. and Osborn, M. 2008

Interpretative Phenomenological Analysis, in: Qualitative Psychology: A Practical Guide to Research Methods, JA Smith (ed.), London: SAGE Publications Ltd., 53-80.

\section{REZIME}

\section{ARHEOLOŠKI PARK KAO} PROIZVOD EMOCIONALNOG DIZAJNA: DIZAJN I ORGANIZACIJA PARKA NA OSNOVU ISTRAŽIVANJA EMOCIJA POSETILACA

KLJUČNe REČI: ARHEOLOŠKi PARK, EMOCIONALNI DIZAJN, FENOMENOLOGIJA, PREZENTACIJA, TURIZAM, ViminaciJum.

Arheološke parkove je neophodno neprestano unapređivati, jer nikad ne možemo reći da je stvaranje nekog arheološkog parka završeno. Kao i kod svakog drugog proizvoda, bitno je stalno istraživati tržište i činiti zadovoljstva korisnicima. Uspeh koji dolazi posle racionalnog upravljanja arheološkim parkovima treba iskoristiti za unapređenje nauke koja je ih u osamnaestom veku, uz radoznalost velikog broja zaljubljenika, i stvorila. Arheologija je privlačna i prijemčiva nauka za veliki broj ljudi i jako doprinosi razvoju turizma. Svako njeno ulaganje se kroz ovu granu privrede može višestruko isplatiti.

Model nastao tokom istraživanja u ovom radu zasnovan je na teoriji emocionalnog dizajna, razvijen uz pomoć društvenih nauka i istraživanja prostora, i namenjen upravama arheoloških parkova i svima onima koji učestvuju u dizajnu i organizaciji jednog parka. Vršenje praktičnih istraživanja među posetiocima će dati rezultate koji će pomoći da se unapredi ukupna prezentacija parka. Ona će dalje učiniti da emocije i iskustva posetilaca budu uvek pozitivni i prepričavaju se.
$\mathrm{Na}$ taj način jedan arheološki park predstavlja uspešan proizvod emocionalnog dizajna.

Predloženo istraživanje prema izvedenom modelu emocionalnog dizajna može koristiti različite metode kojima se prikupljaju podaci, a na osnovu kojih se istražuju emocije posetilaca i njihove interpretacije sopstvenih emocija. Sakupljeni podaci se mogu analizirati preko ovde predloženog interpretativnog fenomenološkog pristupa na osnovu čega će se dobiti zaključci o mogućnostima unapređenja elemenata i procesa koji su deo jednog arheološkog parka.

Iako je u ovom istraživanju arheološki park Viminacijum predstavljen kao primer uspešnog turističkog proizvoda, neophodno je još mnogo raditi na njegovom unapređenju i neprestano razmišljati o njegovom daljem razvoju, da bi emotivni odgovori posetilaca na njegov dizajn, odnosno da bi prihvatanje, zadovoljstvo i nezaboravno iskustvo posle posete ovom parku, bili uvek prisutni kod posetilaca, čak i onih koji u Viminacijum ne dolaze prvi put. Potrebno je napraviti i jednu vrstu plana razvoja ovog parka gde bi se postavili određeni ciljevi i njihovi rokovi ostvarivanja3. U procesu stvaranju ovog plana bi zato od velike pomoći bilo i praktično istraživanje prema modelu emocionalnog dizajna opisano u ovom radu.

3 Videti Maksin, M. et al. 2011: 328-345. 